\title{
眖溶存酸素。超純水による $\mathbb{G} \cong \mathrm{As}(001)$ 表面の洗浄および 洗浄表面に対する熱処理の効果
}

\author{
廣田幸弘・渡辺義夫・福田常男・住友弘二・荻野俊郎 \\ NTT基礎研究所 画 243-01 神奈川県厚木市森の里若宮 3-1 \\ （1996年9月 30 日受付；1996年11月 11 日受理）
}

\begin{abstract}
Cleaning of GaAs(001) Surfaces with Deoxygenated and Deionized Water and the Effects of Thermal Treatments on the Surfaces
\end{abstract}

Yukihiro Hirota, Yoshio Watanabe, Tsuneo Fukuda, Koji Sumitomo and Toshio Ogino

\author{
NTT Basic Research Laboratories \\ 3-1, Morinosato Wakamiya, Atsugi, Kanagawa 243-01
}

(Received September 30, 1996; Accepted November 11, 1996)

\begin{abstract}
We present recent results of synchrotron radiation photoelectron spectroscopy, ultra-violet photoelectron spectroscopy, low energy electron diffraction, scanning tunneling microscopy, and photoluminescence measurements for the horizontal Bridgman-grown $\mathrm{GaAs}(001)$ surface prepared by the deoxygenated and deionized water (DODIW) treatment. We discuss the relationship between surface stoichiometry, surface structure, and the pinning position of surface Fermi level for the DODIW-treated GaAs(001) surface, and point out that the position of surface Fermi level is strongly affected by crystal defects near the surface.
\end{abstract}

\section{1.はじめに}

これまでに，化合物半導体表面上の酸化物を取り除く ためあるいは表面を微細加工するために, 水素ラジカル 照射, プラズマ照射あるいは反応性イオンエッチング等 の手法が用いられてきた。しかし，これらの手法は，化 学的には酸化物のない表面を形成でき, また微細加工を 可能とするものの, 表面近傍の結晶欠陥密度の低減化に は限界が指摘されている。これは，化合物半導体の欠陥 形成エネルギーが小さく, 表面の清浄化および加工の過 程で表面近傍に結晶欠陥が容易に導入されるためであ る。

表面近傍の結晶欠陥は, 化合物半導体の非発光再結合 中心, 表面準位或は電子の散乱体として作用し, レーザ 一の発光特性の劣化, 表面 Fermi 準位のピンニング, 更 には表面電子移動度の低下の原因となる可能性がある。 特に近年, 量子細線, 量子箱等の微細構造を作成する上 で結晶欠陥の少ない低損傷の表面・界面を形成すること は, これら微細構造の電気・光学的特性を向上させる上
で不可避の課題である。

我々は, 結晶欠陥形成の限界, および表面清浄化・微 細加工のデバイス応用上の重要性に鑑み, 従来と異なる 新しい表面処理方法として脱溶存酸素 - 超純水洗浄 (DODIW) 処理を提案してきた ${ }^{1 \sim 6)}$ 。この方法は, 電気 化学反応に基づき半導体表面上の酸化物を除去し, また 反応領域が最表面に限定されるため, プロセスによる結 晶欠陥の誘起を避け得る可能性がある ${ }^{2)}$ 。本処理法と従 来の加工法を組み合わせ表面近傍の欠陥層を取り除いた 場合には, より低損傷の表面・界面を形成できる可能性 もある。

本報告では, まず本処理方法の特徴である脱溶存酸素 化された超純水の製造法について示し, 本処理方法を $\mathrm{GaAs}(001)$ 表面に適用した場合の効果について述べる。 また, 本処理方法が低エネルギープロセスであり表面に 欠陥を誘起させにくい特長を生かし, $\mathrm{GaAs}(001)$ 表面に おける表面構造と表面フェルミ準位（ $\left.E_{\mathrm{FS}}\right)$ の関係を低速 電子線回折 (LEED), 放射光光電子分光 (SRPES), 紫 外線光電子分光（UPS）および走查トンネル顕微鏡 


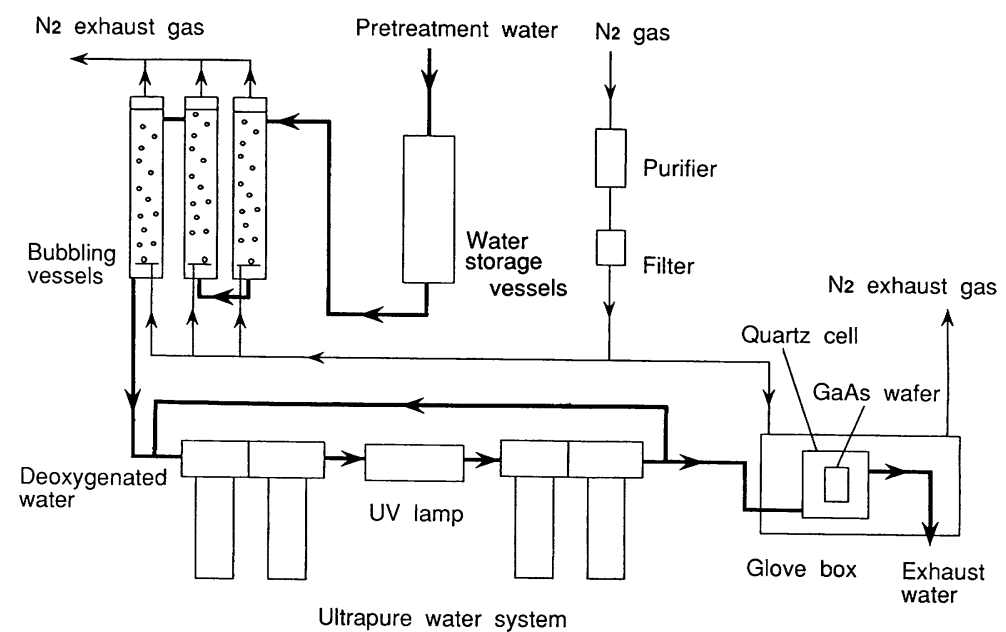

Fig. 1 Experimental de-ionized water treatment apparatus. The dissolved oxygen concentration is reduced by evacuating the water storage vessels, bubbling the water with $\mathrm{N}_{2}$ gas, and using UV radiation to eliminate the residual dissolved oxygen.

（STM）を用いて検討した結果を示す。最後にフォトル ミネセンス（PL）測定の結果をもとに， $E_{\mathrm{Fs}}$ のピンニン グと結晶表面近傍の欠陥の関係について議論する。

\section{2. 実 験 方 法}

\section{1 眖溶存酸素・超純水の製造方法}

Fig. 1に, 本実験で用いた脱溶存酸素・超純水の製造 装置を示す。製造装置は, 真空脱気部, ガスバブリング 部, 超純水装置, およびグローブボックスより構成され る。超純水装置のイオン交換樹脂セルの直前には紫外線 照射ランプが設置されている。通常, 脱気処理をしてい ない超純水中には室温で $2 \sim 5 \mathrm{ppm}$ （飽和值で $8 \mathrm{ppm）の}$ 酸素が含まれている。本装置·゙゙, 超純水中の溶存酸素 （DO）濃度を前段の真空脱気部により約 $300 \mathrm{ppb}$ まで低 減化させている。

Fig. 2に, 次段の窒素バブリング部の全窒素流量とユ ースポイントでの純水中のDO濃度の関係を示す。窒素 バブリング部の窒素流量の增大と共に DO濃度が減少し, また, 紫外線の照射により DO濃度の低減化が促進され ていることがわかる。真空脱気および窒素ガスのバブリ ングによるDO濃度の低下は, ヘンリーの法則に従い溶 存酸素が脱気・排出されるためである。紫外線照射によ る低滅化の促進は, 紫外線照射による水酸基イオンの形 成に溶存酸素が消費されるためである。水酸基イオン自 体は, 純水中の有機物との反応, 反応生成物のイオン交 換樹脂による除去を通じ純水中の有機物濃度を低下させ る働きをする。なお, 本装置のユースポイントでの超純 水の DO濃度, 抵抗率および流量は, それぞれ, 1〜 5

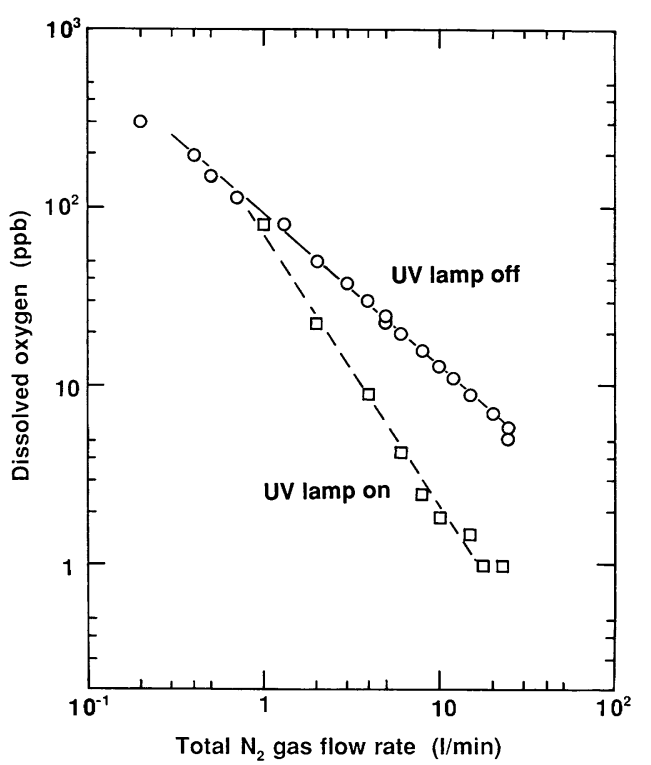

Fig. 2 Dissolved oxygen concentration vs. the total flow rate of $\mathrm{N}_{2}$ gas in bubbling vessels.

$\mathrm{ppb}, 18.2 \mathrm{M} \Omega \cdot \mathrm{cm}, 1.5 \mathrm{l} / \mathrm{min}$ である。

\section{2 具体的な実験方法}

基板には, 水平ブリッジマン（HB）成長 $\mathrm{Si}$ ドープ $\left(n: 8 \times 10^{16} / \mathrm{cm}^{3}\right) \mathrm{GaAs}(001)$ 基板を用いた。GaAs 基板

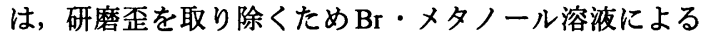
研磨の後, 測定時のチャージアップの影響を防ぐため裏 面に AuGeNi/Auオーミック電極を形成した。オーミック 電極形成時の熱処理温度および時間は, $450^{\circ} \mathrm{C}, 2$ 分間で 
ある。UPS 測定用基板には, 基板表面側に参照用の $\mathrm{Au}$ 電極を設けた。

電極形成の後, $\mathrm{NH}_{4} \mathrm{OH}+\mathrm{H}_{2} \mathrm{O}_{2}+\mathrm{H}_{2} \mathrm{O}(1: 1: 20)$ 混 合液によるエッチング（室温，2分間）を行い, 電極形 成時の熱劣化層を取り除いた。DODIW処理後の基板は, 大気中での炭素污染および表面酸化を避けるためトラン スファーボックスを用い窒素封入により LEED-XPS-UPS 複合装置, SRPES装置およびSTM装置に持ち込んだ。 SRPES 測定は, 高真空中As 圧なしの条件で加熱状態で, LEED 観察，UPS 測定およびSTM 観察は，加熱後に室温 まで冷却した後に行った。各熱処理温度での保持時間は 30 分である。LEED 観察, SRPES 測定およびSTM 観察時 の真空度は, $2 \sim 5 \times 10^{-10}$ Torr, UPS 測定では約 $4 \times 10^{-9}$ Torrである。基板温度の測定には放射温度計を用いた。

SRPES スペクトルに対しては, Gaussian関数によりカ ーブフィテングし，ピーク分離を行った。SRPES測定時 の入射光電子のエネルギーは $120.5 \mathrm{eV}$ である。UPS 測定 の光源には, $\mathrm{He}-\mathrm{II}(40.8 \mathrm{eV})$ ラインを用いた。 $E_{\mathrm{Fs}}$ の位 置は, 試料表面のAu電極から求め, 価電子帯端 (VBM) の位置は価電子帯のUPS 信号とバックグラウンドの外挿 線の交点より求めた。LEEDの入射加速電圧は, 111 $126.5 \mathrm{eV}, \mathrm{STM}$ 観察時のトンネル電流および試料電圧は, $0.08 \sim 0.1 \mathrm{nA},-2.5 \sim-2.2 \mathrm{~V}$ である。

PL測定では，化学エッチングおよびDODIW処理を逐 次行い熱処理後の結晶性の深さ依存性を調べた。PL測

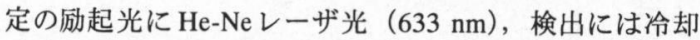
した Geデテクターを用いた。試料の測定温度は液体窒 素温度である。

\section{3. 実験結果と考察}

\section{1 表面組成}

Fig. 3，4 にDODIW処理（20分間）後の GaAs 基板の SRPES Ga-3dおよびAs-3dスペクトルの熱処理温度依存 性を示す。図中の “before heating”, “after cooling”は, 熱処理前, および $500^{\circ} \mathrm{C}$ 加熱後の室温でのスペクトル, “230 ${ }^{\circ} \mathrm{C} ", " 300{ }^{\circ} \mathrm{C} ", “ 400{ }^{\circ} \mathrm{C} ", " 500{ }^{\circ} \mathrm{C} ”$ は昇温下での スペクトルである。Fig. 4 中のAs-3dスペクトルの強度 は, 対応する各 Ga-3dスペクトルの強度（Fig. 3）で規格 化してある。各スペクトルのカーブフィテングにより分 離した成分のピーク位置を実線（基板 $\mathrm{Ga}$, 基板 $\mathrm{As}$ ）お よび破線（過剩As）で示す。

Fig. 3，4より, 熱処理前のAs-3dスペクトルの高結合 エネルギー側に As 酸化物 $\left(\mathrm{As}_{2} \mathrm{O}_{3}: 44.6 \mathrm{eV}\right)$ のピークお よびGa-3dスペクトルの高結合エネルギー側に裾 $\left(\mathrm{Ga}_{2} \mathrm{O}_{3}: 20.4 \mathrm{eV}\right)$ を引いていないことより, $\mathrm{GaAs}(001)$ 表面の酸化物はDODIW処理により取り除かれているこ

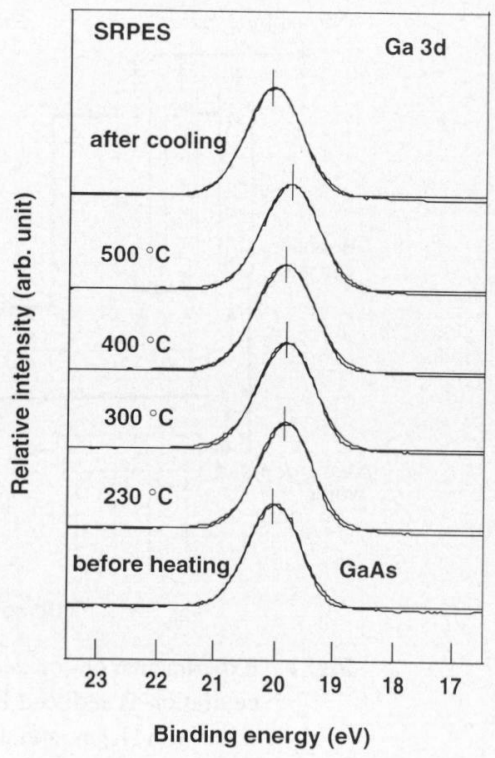

Fig. 3 Ga 3d core level spectra vs. various temperature.

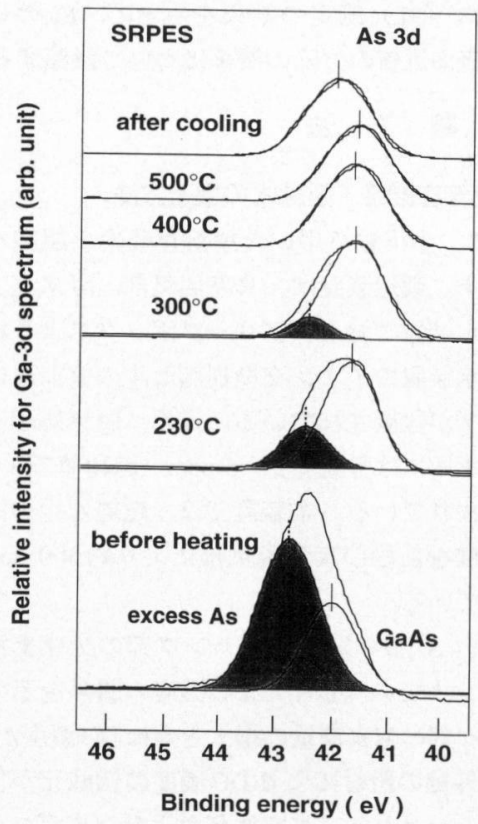

Fig. 4 As 3d core level spectra for various temperature. The signal height is normalized with that of $\mathrm{Ga} 3 \mathrm{~d}$ core level spectra at each temperature.

とがわかる゙。

Fig. 4 に示すように熱処理前のAs-3dスペクトル強度 は, 熱処理前の Ga-3dスペクトル強度（Fig. 3）より大き い。感度補正後のAs-3d およびGa-3dスペクトルの積分 強度比 $(r)$ は, 熱処理前では3.5となり, DODIW処理 
後に表面に過剩As 層が形成されていることを示してい $る^{2 \sim 4)}$ 。過剩As 層の形成は, DODIW 処理時に基板の Ga 原子が水分子と反応・解離し, As 原子が表面に取り残 されるためである22。この表面の過剩Asは, 熱処理温度 の上昇に伴い次第に熱脱離する。Fig. 4より, 基板自体 の As 元素のピークは, 主に $300{ }^{\circ} \mathrm{C}$ 以上で現れ, $400{ }^{\circ} \mathrm{C}$ 以上では過剩Asピークは表面に存在しないことがわ かる。積分強度比（r) は, $230{ }^{\circ} \mathrm{C}$ で $2.0,300{ }^{\circ} \mathrm{C}$ で 1.5 , $400 \sim 500{ }^{\circ} \mathrm{C}$ では1〜 1.2 に減少する ${ }^{4}$ 。

As-3dスペクトルのピーク位置は, 過剩Asの熱脱離に より, $42.5 \mathrm{eV}$ (熱処理前) から $41.6 \mathrm{eV}$ まで見掛け上変

\section{(a) Room temperature}

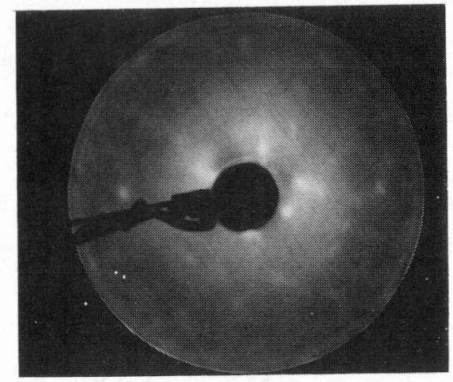

(b) $200^{\circ} \mathrm{C}$

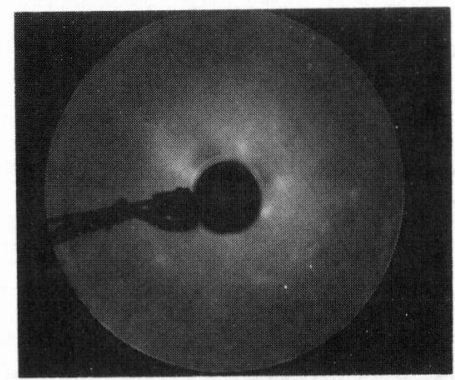

(c) $450^{\circ} \mathrm{C}$

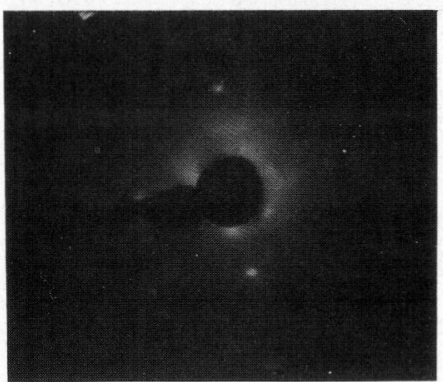

化するものの，ピーク分離後の基板の As-3d ピーク位置 は熱処理下では Ga-3d ピーク位置と同程度の変化（0.2 $0.4 \mathrm{eV})$ を示し温度上昇に伴い低結合エネルギー側に移 動する。基板As と過剩 As のピーク位置の差は, “before heating”, “ $230{ }^{\circ} \mathrm{C} ”$, および “ $300{ }^{\circ} \mathrm{C} ”$ ともに $0.8 \mathrm{eV}$ 程度 である (Fig. 4) ${ }^{8)}$ 。本報では示さないものの, 昇温時に は価電子帯端も低結合エネルギー側へ移動する。この現 象は, 熱処理温度 $500{ }^{\circ} \mathrm{C}$ 以下では温度に対し可逆的であ ることから ${ }^{4)}$, photovoltaic効果 ${ }^{9}{ }^{10)}$ による昇温時のバン ド曲の増大に起因していると考えられる。photovoltaic効 果による価電子帯端位置の移動は, $230{ }^{\circ} \mathrm{C}$ で顕著に現わ (d) $500^{\circ} \mathrm{C}$

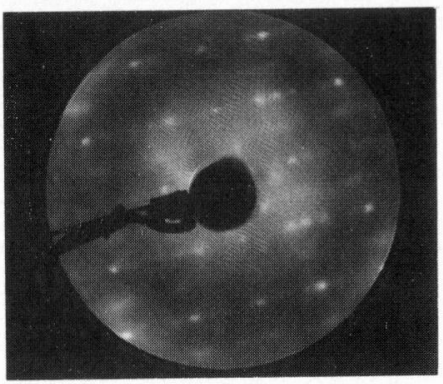

(e) $550^{\circ} \mathrm{C}$

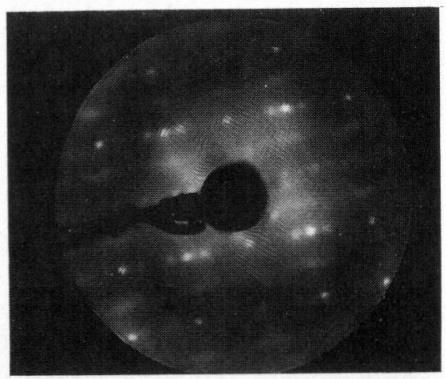

(f) $600{ }^{\circ} \mathrm{C}$

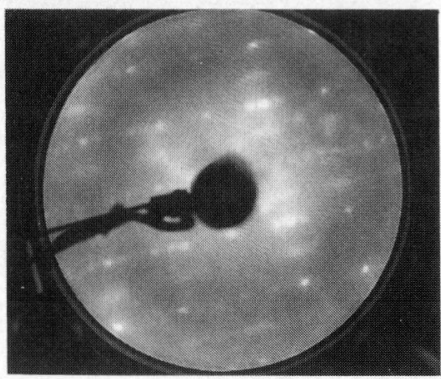

Fig. 5 LEED patterns of the DODIW-treated $\mathrm{GaAs}(001)$ surface after cooling to room temperature in UHV. LEED patterns were taken with $112.6-126.5 \mathrm{eV}$ electrons. (a) Before heating, (b) after heating to $200^{\circ} \mathrm{C}$, (c) $450^{\circ} \mathrm{C}$, (d) $500^{\circ} \mathrm{C}$, (e) $550^{\circ} \mathrm{C}$, and (f) $600^{\circ} \mathrm{C}$. 
れ Ga-3d, As-3dピークと同程度の変化 $(0.2 \sim 0.4 \mathrm{eV})$ を 示す ${ }^{4)}$ 。

\section{2 表面構造}

Fig. 5に, 真空加熱 $\left(200{ }^{\circ} \mathrm{C} \sim 600^{\circ} \mathrm{C}\right)$ 後の室温での LEED 観察の結果を示す。Fig. 5 (a) および（b）より, $200{ }^{\circ} \mathrm{C}$ ま゙の加熱では, 表面でのアモルファス構造の過 剩As層の存在に対応しハローパターンのみが観察され る。 $450{ }^{\circ} \mathrm{C}$ では, 過剩 Asはほぼ表面から脱離するた め $1 \times 1$ 構造を示す (Fig. 5 (c))。熱処理温度 $480{ }^{\circ} \mathrm{C} \sim$ $600{ }^{\circ} \mathrm{C}$ (Fig. 5 (d) 〜 (f)) では, $2 \times 4$ 構造が現れる。

$480{ }^{\circ} \mathrm{C}$ 以上での $2 \times 4$ 構造の出現はSTM観察でも確認 できる5)。Fig. 6に, DODIW処理後, $515^{\circ} \mathrm{C}$ で加熱した 後の HB成長 $\mathrm{GaAs}(001)$ 表面のSTM像を示す。STMの走 查範囲は, $1000 \AA \times 1000 \AA$ である。Fig. 6に示すように 熱処理後の $\mathrm{GaAs}(001)$ 表面には，不規則なステップに区 切られた島状およびテラス状の構造が認められる。各テ ラス上には，[110]方向にそって伸びる明るい線と暗い 線が存在する。Fig. 6を拡大した場合には, 明るい線の 中には[110]方向にそって幅 $8 \AA$ セルが並んだ構造が認め
られた。これは, DODIW処理 HB成長 GaAs(001)表面に おいても，MBE成長表面と同様に $2 \times 4$ 構造が現れるこ とを示している5 6, 11, 12)。なお, 熱処理前のDODIW処理 表面には過剩As層の存在によると思われる $20 \sim 50 \AA$ 程 度のランダムな構造が認められた。

\section{3 表面 Fermi 準位の熱処理温度依存性}

DODIW 処理 GaAs(001)表面のUPS 測定から求めた価電 子带スペクトルの熱処理温度依存性をFig. 7 に示す。測 定は, photovoltaic 効果による影響を避けるため室温で行 った。 $E_{\mathrm{FS}}$ (雺点) は, 表面の Au電極のUPS 測定から求 めた。図中に価電子带端（VBM）の位置を矢印で示す。 Fig. 7 より, 熱処理温度の増大に伴い, VBMが次第に $E_{\mathrm{FS}}$ に近ゔくことがわかる。

Fig. 8 に Fig. 7 の UPS 測定から求めた $E_{\mathrm{FS}}$ の值, および LEED 観察から得られた表面構造の熱処理温度依存性の 結果をまとめる。Fig. 8 には，低キャリアー濃度（ $n$ : $\left.8 \times 10^{16} / \mathrm{cm}^{3}\right)$ 基板に加え高キャリアー濃度（ $n: 2 \times$ $10^{18} / \mathrm{cm}^{3}$ ) 基板の結果も示してある。Fig. 8 より低キャリ アー濃度基板では, 室温から $450^{\circ} \mathrm{C}$ ま゙゙ $E_{\mathrm{FS}}$ は, VBM

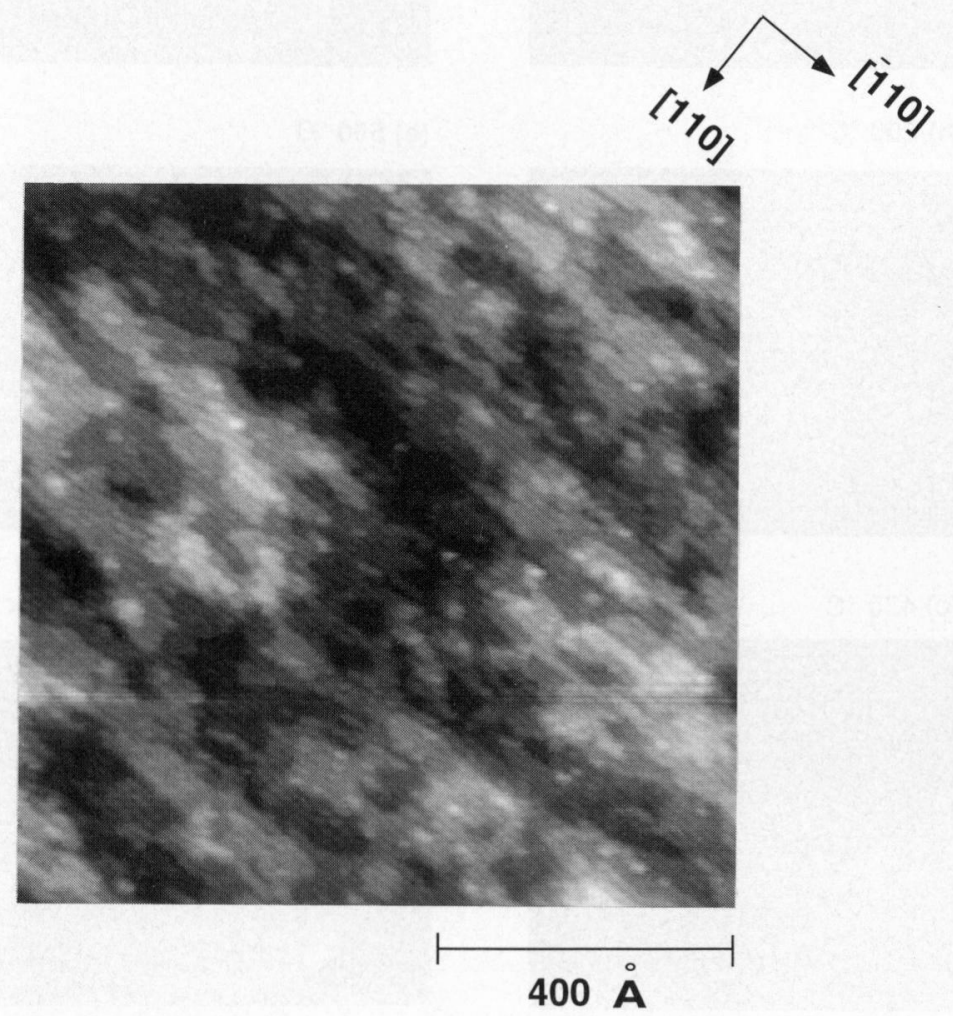

Fig. 6 A $1000 \AA \times 1000 \AA$ image of $2 \times 4$ reconstruction for a $n$-type $(8 \times$ $\left.10^{16} / \mathrm{cm}^{3}\right) \mathrm{GaAs}(001)$ surface after cooling to room temperature from $515^{\circ} \mathrm{C}$. The STM image is obtained with a tunneling current of $0.05 \mathrm{nA}$ and sample bias of $-2.5 \mathrm{~V}$. 


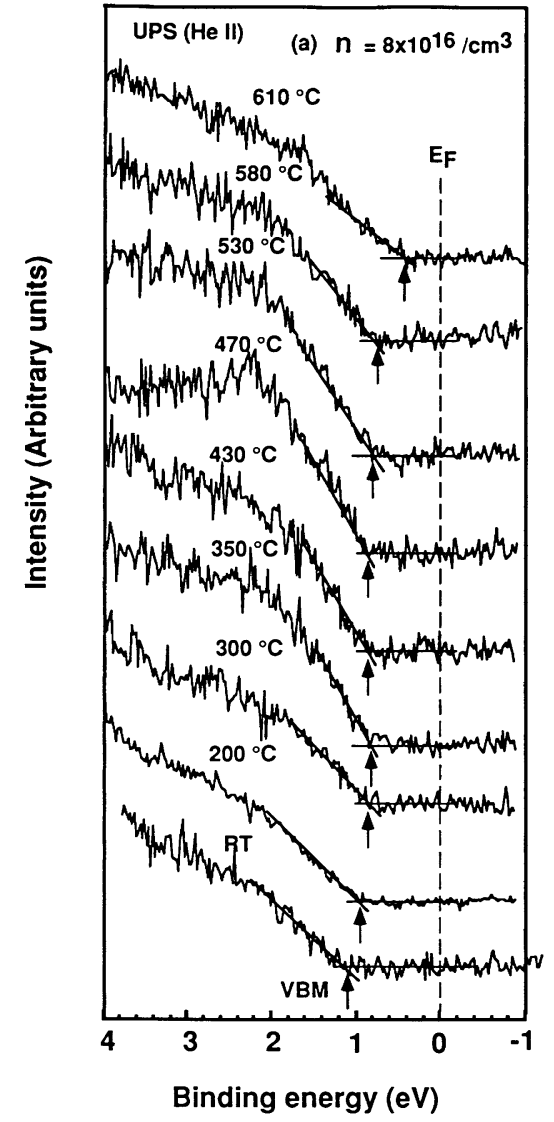

Fig. 7 Valence band spectra of the lightly Si-doped $(n=8 \times$ $\left.10^{16} / \mathrm{cm}^{3}\right) \mathrm{GaAs}(001)$ surface prepared by DODIW treatment after heating at various temperatures. These data were obtained at room temperature by UPS.

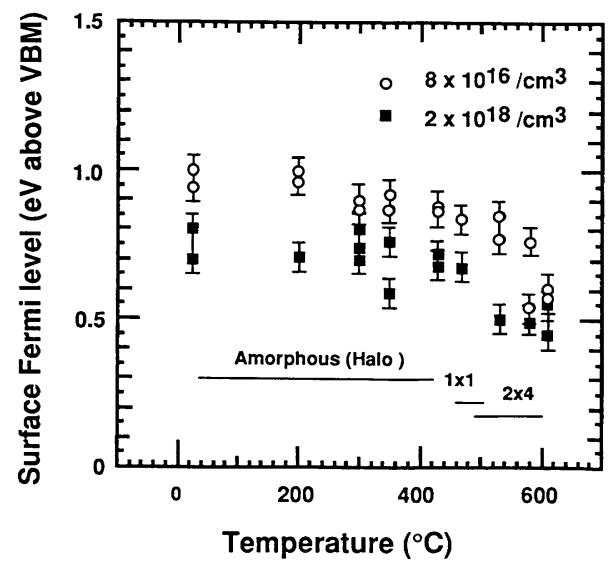

Fig. 8 The surface Fermi level positions deduced from the VBM of the VB emission spectra as a function of temperature. The temperature range of each surface structure is indicated by the solid lines.
より $0.85 \sim 1.0 \mathrm{eV}$, 高キャリアー濃度基板では $0.68 \sim 0.8$ $\mathrm{eV}$ の範囲にある。 $480^{\circ} \mathrm{C}$ 以上では, 両基板とも熱処理温

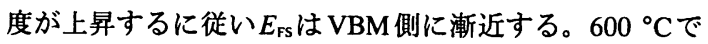
の $E_{\mathrm{Fs}}$ の漸近点は, 低キャリアー濃度基板で VBMより $0.54 \mathrm{eV}$, 高キャリアー濃度基板で VBMより $0.45 \mathrm{eV}$ であ る。 $E_{\mathrm{rs}}$ と表面構造の関係で注目すべき点は，450～ 480 ${ }^{\circ} \mathrm{C}$ で, 表面が $1 \times 1$ 構造から $2 \times 4$ 構造に変化しても, $E_{\mathrm{FS}}$ は急激には変化せず, また $480{ }^{\circ} \mathrm{C}$ 以上で $2 \times 4$ 構造を 保持していても, 熱処理温度の上昇に伴いVBM側に近 うくことである。更に，高キャリアー濃度基板の $E_{\mathrm{Fs}}$ は， 低キャリアー濃度基板より全温度領域でよりVBM 側の 位置にある。 $E_{\mathrm{Fs}}$ の熱処理による VBM 側への漸近は， DODIW処理した MBE成長 GaAs 基板（V/III：30, 成長 温度 : $680^{\circ} \mathrm{C}$ ) でも認められた。

\section{4 フォトルミネスセンスによる検討}

Fig.9に，低キャリアー濃度 $\left(n: 8 \times 10^{16} / \mathrm{cm}^{3}\right)$ 基板の PL測定の結果を示す。Fig. 9 (e), (a) は, $600{ }^{\circ} \mathrm{C}$ での 熱処理前後のPLスペクトル，（b）～（d）は熱処理後に 表面を化学エッチングした基板のPLスペクトルである。 表面からのエッチング深さを図中に示す。各PLスペク トル強度は, 熱処理前のスペクトル（e）を基準とした。

Fig. 9より, PLスペクトルの形状およびピーク強度が

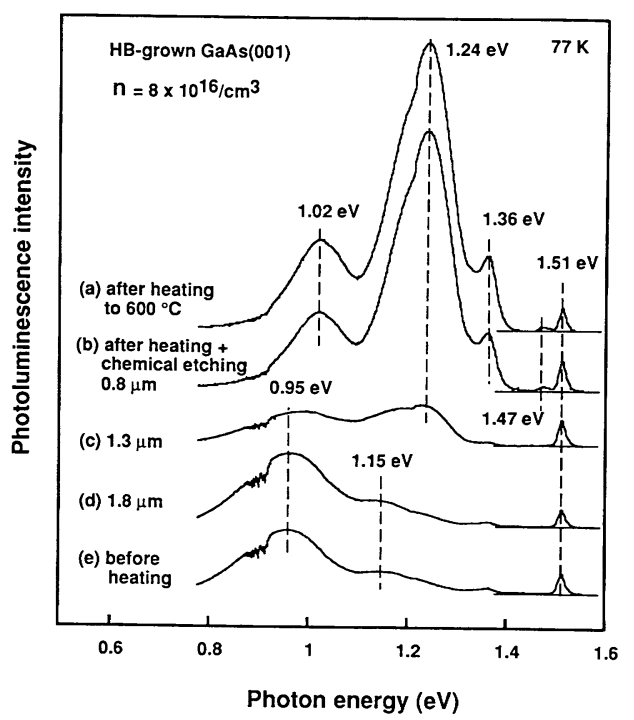

Fig. 9 Photoluminescence spectrum changes caused by step etching for the lightly $\left(8 \times 10^{16} / \mathrm{cm}^{3}\right)$ Si-doped $\mathrm{GaAs}(001)$ surfaces after heating to $600^{\circ} \mathrm{C}$ in UHV. The surface were rinsed with DODIW to remove surface oxides after chemical etching. (a) After heating to 600 ${ }^{\circ} \mathrm{C}$, (b) after heating and chemical etching to a depth of about $0.8 \mu \mathrm{m}$, (c) $1.3 \mu \mathrm{m}$, and (d) $1.8 \mu \mathrm{m}$. (e) Before heating. 
エッチング深さに依存していることがわかる。熱処理表

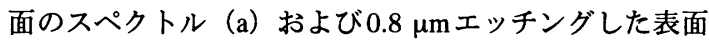
のスペクトル（b）では, バンド端ードナー間の遷移発光 $1.51 \mathrm{eV}$ に加え ${ }^{13)}, 1.47 \mathrm{eV}, 1.36 \mathrm{eV}, 1.24 \mathrm{eV}, 1.02 \mathrm{eV}$ にピ 一クを持つ発光が存在する。一方, $1.3 \mu \mathrm{m}$ （：スペクト ル (c)) および $1.8 \mu \mathrm{m}$ エッチングした後（：スペクトル (d)）では, $1.24 \mathrm{eV}$ の発光ピーク強度は減少し, $1.47 \mathrm{eV}$ の発光ピークも認められない。また, $1.36 \mathrm{eV}$ の発光ピ 一クもスペクトル（a）および（b）と比較し非常に小さ い。スペクトル（d）は，熱処理前の発光スペクトル （e）とほぼ同一である。これは，化学エッチングによっ て結晶欠陥層幅が隇少し表面近傍の結晶状態が熱処理前 の基板に近づくためである。

$1.36 \mathrm{eV}$ の発光ピークはAs空孔と Siアクセプター間遷 移 $\left(\mathrm{V}_{\mathrm{As}}{ }^{+}-\mathrm{Si}_{\mathrm{As}}{ }^{-}\right)^{13,14)}, 1.24 \mathrm{eV}$ にピークを持つ発光は $\mathrm{Ga}$ 空 孔-Si ドナー間遷移 ${ }^{13 \sim 15)}, 1.47 \mathrm{eV}$ の発光は Si ドナー $-\mathrm{Si}$ アクセプター間遷移 $\left(\mathrm{Si}_{\mathrm{Ga}}{ }^{+}-\mathrm{Si}_{\mathrm{As}}{ }^{-}\right)^{13,15,16)}$ による発光と考 えられ，スペクトル（a）および（b）での $1.36 \mathrm{eVおよ}$ び1.47 eVの発光ピークの出現は, 熱処理後に表面近傍 では両極性のSi原子がAsサイトにも入り込みアクセプ ターとして働いている可能性を示唆している ${ }^{17)} 1.15 \mathrm{eV}$ の発光ピークは, $\mathrm{Si}$ ドナーと $\mathrm{Ga}$ 空孔によるもの $\left(\mathrm{Si}_{\mathrm{Ga}}{ }^{+}\right.$ $\mathrm{V}_{\mathrm{Ga}}{ }^{3-}$ ) である ${ }^{15)}$ 。熱処理前の発光スペクトル（e）およ び（d）に見られる $0.95 \mathrm{eV}$ 発光ピークは， $\mathrm{V}_{\mathrm{As}} \mathrm{V}_{\mathrm{Ga}}$ と Si ドナーの複合体 $\left(\mathrm{V}_{\mathrm{As}}{ }^{+} \mathrm{V}_{\mathrm{Ga}}{ }^{2-}-\mathrm{Si}_{\mathrm{Ga}}{ }^{+}\right)$に起因すると考えら れる ${ }^{18.19) 。}$

以上のPL測定の結果は，熱処理によって表面近傍に $\mathrm{Ga}$ 空孔およびAs 空孔の新たな形成およびその拡散が生 じ，この空孔を含む結晶欠陥層が， $600{ }^{\circ} \mathrm{C} て ゙$ 熱処理した 低キャリアー濃度基板では表面から $1.3 \sim 1.8 \mu \mathrm{m}$ まで及 んでいることを示している。

\section{5 熱迈理による結晶欠陥の形成}

熱処理による $E_{\mathrm{Fs}}$ のVBMへの漸近は，以下の欠陥反応 を考えると説明できる。

$$
\mathrm{V}_{\mathrm{As}} \longleftrightarrow \mathrm{V}_{\mathrm{Ga}}+\mathrm{Ga}_{\mathrm{As}}
$$

ここで, $\mathrm{V}_{\mathrm{As}}, \mathrm{V}_{\mathrm{Ga}}, \mathrm{Ga}_{\mathrm{As}}$ は，それぞれAs空孔， $\mathrm{Ga}$ 空 孔， Gaアンチサイト欠陥である。（1）式は，As空孔へ の $\mathrm{Ga}$ 原子のホッピングにより $\mathrm{Ga}$ 空孔と $\mathrm{Ga}$ アンチサイ 卜欠陷が形成されることを示している。

いま，基板構成元素であるAs原子の熱脱離により， As 空孔が表面から逐次形成され表面近傍での As 空孔数 が増大すると, 反応式（1）は右側に進む。すなわち, 熱処理温度の上昇に伴い表面からのAs原子の脱離, As 空孔の形成に伴い表面近傍に $\mathrm{Ga}$ 空孔と $\mathrm{Ga}$ アンチサイト 欠陥数が同時に増大する。またAs空孔が結晶内部へ拡 散するに従い, $\mathrm{Ga}$ 空孔と $\mathrm{Ga}$ アンチサイト欠陷も結晶内
部に次第に形成される。As 空孔は深いドナー ${ }^{20,21)}, \mathrm{Ga}$ 空孔と Gaアンチサイト欠陥は深いアクセプター16, 20 22) となるため, 表面近傍では次第にアクセプタ一数が増大 する。熱処理温度の增大に伴い表面近傍でアクセプター 数が増大すれば， $E_{\mathrm{Fs}}$ はこの潹いアクセプター準位に漸 近する。

表面近傍に誘起される結晶欠陥が， $E_{\mathrm{Fs}}$ の移動の原因 ならば，この結晶欠陥層を取り除いた場合には， $E_{\mathrm{FS}}$ は 熱処理前の值に復帰するはずである。実際に, 高真空下 $600{ }^{\circ} \mathrm{C}$ で熱処理し表面から約 $2 \mu \mathrm{m}$ エッチングした場合 には, $E_{\mathrm{Fs}}$ の位置は熱処理後の $0.54 \mathrm{eVから} 0.88 \sim 0.93 \mathrm{eV}$ に回復する。これは， $E_{\mathrm{Fs}}$ のピンニングに表面近傍の結 晶欠陥が深く関与していることを示唆している。ここで， 特徴的な点は, $\mathrm{HB}$ 成長 $\mathrm{GaAs}(001)$ 表面では表面が $2 \times 4$ 構造を示していても, 表面近傍に結晶欠陥が多数存在し, $E_{\mathrm{FS}}$ はVBMに漸近することである。これは，GaAs(001)表 面では最表面の構造のみで表面電子状態を議論できない ことを示唆している。

\section{4.むす び}

本報では, HB成長 $\mathrm{GaAs}(001)$ 表面を例に脱溶存酸素・ 超純水洗浄 (DODIW) 処理の効果, および本処理法で 形成した HB成長 $\mathrm{GaAs}(001)$ 表面に対する熱処理の効果に ついて示した。以下に，結果をまとめる。

(1) DODIW 処理により酸化物のない GaAs 表面を形成 できる。

（2）極低溶存酸素濃度（1～5 ppb）の条件では表面に 過剩As層が形成される。

（3）過剩 As 層の熱脱離後， $1 \times 1 ， 2 \times 4$ 構造が現れ る。

(4) 表面フェルミ準位は, 熱処理温度の上昇に伴い価 電子带端側に漸近する。

（5）表面フェルミ準位の価電子帯端側への漸近は，熱 処理により誘起される表面近傍の結晶欠陥により説明で きる。

本処理方法は, 結晶成長法, ドーピング量, ドーパン 卜種および面方位に関係なく酸化物のないかつ低損傷の 表面を形成できる。これは，DODIW処理が上記の因子 および熱処理が表面電子状態に与える影響を探る上で有 力な手段となることを示している。本報で示した，450 ${ }^{\circ} \mathrm{C}$ 以下でのキャリアー濃度差 $\left(8 \times 10^{16} / \mathrm{cm}^{3}\right.$ および $2 \times$ $\left.10^{18} / \mathrm{cm}^{3}\right)$ による $E_{\mathrm{FS}}$ の違いについても基板の $\mathrm{Ga}$ 空孔濃度

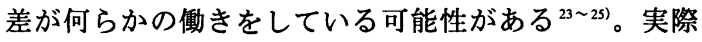
に, Si高ドープ基板では, Ga空孔に関係した強いPL発 光ピーク $(1.15 \mathrm{eV})$ が観察され6)，またドープ量の増大 に伴い $\mathrm{Ga}$ 空孔濃度が增大することが報告されている ${ }^{24)}$ 。 
今後, 結晶成長法による結晶性の差, 表面近㥬および結 晶内部の結晶欠陥と表面フェルミ準位の関係を含めた検 討が必要と考えられる ${ }^{25)}$

\section{謝辞}

本研究の遂行にあたり，有益な討論をして頂いた本間 芳和博士, 堀越佳治博士に感謝します。また, XPS 測 定, UPS 測定，PL測定にご協力頂いた青木延枝氏，鈴 木峰晴博士, ならびに高幣謙一郎博士に感謝します。

\section{文 献}

1）廣田幸弘, 本間芳和, 杉井清昌, 峰岸延枝: 表面科学 12, 381 (1991).

2) Y. Hirota: J. Appl. Phys. 75 , 1798 (1994).

3) Y. Hirota, T. Ogino, Y. Watanabe and M. Oshima: Appl. Phys. Lett. 65, 2036 (1994).

4) Y. Hirota, T.Ogino, Y. Watanabe and M. Oshima: J. Vac. Sci. Technol. A 13, 1676 (1995).

5) Y. Hirota and T. Fukuda: Appl. Phys. Lett. 22, 2837 (1995).

6) Y. Hirota and K. Sumitomo: J. Appl. Phys. 79, 7785 (1996).

7) Y. Mizokawa: J. Electron Spectrosc. Relat. Phenom. 14, 129 (1978).

8) G. Leonhardt, A. Berndtsson, J. Hedman, M. Klasson, P. Nilsson and C. Nordling: Phys. Status Solidi B 60, 241 (1973).

9) S. Chang, I.M. Vitomirov, L.J. Brillson, D.F. Rioux and
M.H. Hecht: Phys. Rev. B 41, 12299 (1990).

10) M.H. Hecht: Phys. Rev. B 41, 7918 (1990).

11) M.D. Pashley, K.W. Haberern, W. Friday, J.M. Woodall and P.D. Kirchner: Phys. Rev. Lett. 60, 2176 (1988) .

12) M.D. Pashley, K.W. Haberern and J.M. Woodall: J. Vac. Sci. Technol. B 6, 1468 (1988).

13) L. Pavesi and M. Guzzi: J. Appl. Phys. 75, 4779 (1994).

14) H. Birey and J. Sites: J. Appl. Phys. 51, 619 (1980).

15) A.A. Bonapasta, B. Bonanni, M. Capizzi, L. Cherubini, V. Emiliani, A. Frova and F. Sarto: J. Appl. Phys. 73, 3326 (1993).

16) A. Jorio, A. Wang, M. Parenteau, C. Carlone, N.L. Rowell and S.M. Khanna: Phys. Rev. B 50, 1557 (1994).

17) J. Maguire, R.C. Newman and R.B. Beall: J. Phys. C 19, 1897 (1986).

18) M.A. Reshchikov, A.A. Gutkin and V.E. Sedov: Material Science Forum 196-201, 237 (1995).

19) A.A. Gutkin, N.S. Averkiev, M.A. Reshchikov and V.E. Sedov: Material Science Forum 196-201, 231 (1995).

20) H.E. Evans, P.C. Rice-Evans, D.L. Smith, G.A. Gledhill and A. M. Moore: J. Phys. CD4, 1859 (1992).

21) S.Y. Chiang and G.L. Peason: J. Appl. Phys. 46, 2986 (1975).

22) C. Corbel, F. Pierre, K. Saarinen, P. Hautojarvi and P. Moser: Phys. Rev. B 45, 3386 (1992).

23) G.A. Baraff and M. Schluter: Phys. Pev. B 33, 7346 (1986).

24) J.-L. Lee, L. Wei, S. Tanigawa and M. Kawabe: J. Appl. Phys. 68, 5571 (1990).

25) C.-H. Chen and T.Y. Tan: Appl. Phys. A 61, 397 (1995). 